\title{
Osmoregulators in Hymenaea courbaril and Hymenaea stigonocarpa under water stress and rehydration
}

\author{
Luma Castro de Souza ${ }^{1}$ - Luana Moraes da $\mathrm{Luz}^{2} \cdot$ Jéssica Taynara da Silva Martins ${ }^{3}$. \\ Cândido Ferreira de Oliveira Neto ${ }^{3} \cdot$ Juscelino Gonçalves Palheta $^{3}$ • \\ Tamires Borges de Oliveira ${ }^{3}$ Ediane Conceição Alves ${ }^{4} \cdot$ Risely Ferraz de Almeida ${ }^{5}$. \\ Raimundo Leonardo Lima de Oliveira ${ }^{3}$ - Roberto Cezar Lobo da Costa ${ }^{3}$. \\ Nariane Quaresma Vilhena'
}

Received: 7 September 2016/Accepted: 23 February 2017/Published online: 20 December 2017

(c) Northeast Forestry University and Springer-Verlag GmbH Germany 2017

\begin{abstract}
The objective of this work was to evaluate the effect of different water deficiency and rehydration levels on the concentrations of osmoregulators in two plant species (Hymenaea courbaril and H. Stigonocarpa) in the Amazon. We adopted a $2 \times 5 \times 5$ factorial system, referring to 2 species (H. courbaril and H. stigonocarpa) and 5 stages of hydration and rehydration. The five hydration and rehydration stages were established in: (1) Control treatment E0; (2) Plants with 13 days of stress after incubation-E13; (3) Plants with 26 days of stress E26; (4) The plants that were established after 26 days after incubation and rehydrated for two days (RD2); (5) rehydrated for two days (RD4). The plants that were established after
\end{abstract}

Project funding: This work was supported by the Universidade Federal Rural da Amazônia.

The online version is available at http://www.springerlink.com

Corresponding editor: Chai Ruihai.

Luma Castro de Souza

lumasouza30@hotmail.com

1 Universidade estadual paulista júlio de mesquita filho, Jaboticabal, SP 14884-900, Brazil

2 Universidade Federal Rural da Amazônia (UFRA), Campus Capanema, Capanema 68700-030, Brazil

3 Universidade Federal Rural da Amazônia, Campus Belém, Belém 66077-830, Brazil

4 Universidade Federal de Viçosa (UFV), Viçosa 36570-900, Brazil

5 Universidade Estadual Paulista Júlio de Mesquita Fiho (UNESP), Jaboticabal 14884-900, Brazil

6 Universidade do Estado do Pará (UEPA), Belém 66113-200, Brazil
26 days after incubation and rehydrated for four days. The experiment totaled fifty young plants with five replicates. Biochemical measurements were performed at the beginning of the experiment (E0) at 13 (E13) and 26 (E26) days after the water stress, in which the plants were rehydrated, repeating the analyses after two (RD2) and four (RD4) days. Both species increased the sucrose concentration by $18 \%$, with a decrease of $52 \%$ in starch content. The RD4 time presented the highest mean starch concentration $\left(0.19 \mathrm{mmol} \mathrm{g}^{-1}\right.$ of the residue for $H$. courbaril and $0.27 \mathrm{mmol} \mathrm{g}^{-1}$ of residue for $H$. stigonocarpa). Increased proline concentrations were recorded for controls until RD2 for both species. For glycine betaine, the highest increases in treatments E26 and RD2 were observed for the $H$. courbaril species. Our rehydration period was not sufficient for total recovery of pre-stress concentrations of all studied solutes.

Keywords Amazonia - Water stress - Osmotic adjustment $\cdot$ Proline $\cdot$ Sucrose

\section{Introduction}

Environmental stresses affect plant growth and can cause decreased performance of crops (Carlin and Santos 2009). Water deficiency is one of the major limitations affecting world agriculture, due to its negative effects on plant growth and development. Water stress, caused by heat and thermal shock, as well as salinity and oxygen deficiency are the major stressors that restrict plant growth (Batista et al. 2008; Lopes et al. 2011). Thus, one of the great challenges of agriculture is to increase crop productivity in environments with deficient water supply (Carlin and Santos 2009). Studies of the biochemical behavior of plants 
in these environments are needed to identify plants that are tolerant to these abiotic stress.

In the Brazilian Amazon the genus Hymenaea L. has been gaining importance for several researchers for presenting adaptation in inappropriate areas, such as water deficiency. It is considered a great relevance in forestry and economic aspects (Nascimento et al. 2011). Hymenaea courbaril L. is a promising species for reforestation and recovery programs in degraded areas. It has a wide geographical distribution and survives in environments with diverse climatic and soil characteristics (Paiva and Vital 2003).

Nascimento et al. (2011) reported that water deficit affects dry matter production in $H$. courbaril. Pimentel (1999) reported that water stress leads to increase in concentrations of soluble carbohydrates. Increase in soluble carbohydrate concentrations contributes to regulation of photosynthetic and respiratory processes (Pimentel 2004). Santos Filho et al. (2010) verified increase in the carbohydrate content of roots of the $H$. courbaril subjected to water deficit.

Hymenaea stigonocarpa can survive in abandoned pasture and being recommended for recovery of degraded areas (Barbosa and Martins 2003) in water deficiency conditions.

The plants in water deficiency conditions trigger the greater energy demand to the production due to the problems in the plant physiology (Larcher 2006), such as: Sucrose, starch, proline and Glycine betaine content. Thus, the search for cultivars tolerant to environmental stress has increased interest in physiological and biochemical mechanisms that can indicate response to various environmental conditions (Kavi Kishor et al. 2005), since these tolerance mechanisms in plants are not yet fully explained (Grennan 2006).

We tested the hypothesis that concentrations of osmoregulators in $H$. courbaril and $H$. stigonocarpa are influenced by levels of water deficiency and rehydration.

\section{Materials and methods}

\section{Location and experiment performance}

The experiment was conducted in a greenhouse at Universidade Federal da Amazônia in Brazil, between May and September 2013. To assess the concentrations of osmoregulators in plants, we studied two plant species, $H$. courbaril (JA) and $H$. stigonocarpa (JU), popularly known as courbaril and jatobá-do-cerrado.

The experiment was run with a $2 \times 5$ factorial system, with five replicates, referring to: 2 species $(H$. courbaril and $H$. stigonocarpa); five stages of hydration and rehydration (1: control treatment E0; 2: plants with 13 days of stress after incubation-E13; 3: Plants with 26 days of stress E26; 4: The plants were established after 26 days after incubation and rehydrated for two days (RD2); 5: rehydrated for two days (RD4)).

Plants were grown in pots containing $18 \mathrm{~kg}$ of mediumtextured yellow latosol and irrigated to field capacity on alternate days, kept in an environment with natural lighting with an average of photosynthetically active radiation (PAR) of $1130 \mu \mathrm{mol} \mathrm{m} \mathrm{m}^{-2} \mathrm{~s}^{-1}$, reaching daytime temperature of $30 \pm{ }^{\circ} \mathrm{C}$ with air relative humidity variation between 60.5 and $80 \%$.

Biochemical responses to water deficit were evaluated on days 0,13 and 26, and responses to rehydration were measured on the days 2 and 4 after the 26 days of water deficit. All pots were weighed every other day in order to maintain the water capacity of all groups.

\section{Osmoregulator evaluation}

At the end of the experiment, the fresh plant material was used to quantify nitrate reductase activity. Collected leaves were dried in an air circulation oven at $65{ }^{\circ} \mathrm{C}$ for $72 \mathrm{~h}$. They were then ground and packed in hermetically sealed vials pening biochemical analyses. Seedling behavioral responses were evaluated using the methods described below.

Starch concentrations were quantified using the method described by Dubois et al. (1956) in which ethanolic extraction $(50 \mathrm{mg}$ of the roots and leaf dry mass) was carried out in $5.0 \mathrm{~mL}$ of $80 \%$ ethanol for $30 \mathrm{~min}$ at $80{ }^{\circ} \mathrm{C}$. Further extraction was performed with $5.0 \mathrm{~mL}$ of $30 \%$ $\mathrm{HClO} 4$ for $30 \mathrm{~min}$ at $25^{\circ} \mathrm{C}$. The supernatants collected from the first and second extractions were centrifuged (2000 rpm for $10 \mathrm{~min}$ ) and the supernatants of each extraction were pooled and calibrated to a volume to $10 \mathrm{~mL}$ with distilled water to obtain the total extract.

Sucrose content was quantified using the Van Handel method (1968), in which samples of $30 \mathrm{mg}$ of root and leaf dry mass were used. These were homogenized in $2.0 \mathrm{~mL}$ volume Eppendorf tubes containing $1.5 \mathrm{~mL}$ of $\mathrm{MWC}$ solution (methanol, chloroform and water, 12:5:3 v/v/v), and agitated in a shaker for $30 \mathrm{~min}$ at room temperature. The homogenate was centrifuged at 10,000 rpm for $10 \mathrm{~min}$ and the supernatant was collected. The residuals were again extracted with equal volume of MCW, followed by a new centrifugation and another collection of supernatants in order to obtain the total extract.

Glycine betaine content was quantified using the method described by Grieve and Grattan (1983) in which $25 \mathrm{mg}$ of lyophilized or oven dried DM were transferred into $2 \mathrm{~mL}$ Eppendorf tubes and $2 \mathrm{~mL}$ of distilled water were added. The solution was stirred for $4 \mathrm{~h}$ in the shaker at $25^{\circ} \mathrm{C}$ (cold 
extraction) and centrifuged at $10,000 \mathrm{rpm}$ for $10 \mathrm{~min}$ at $25{ }^{\circ} \mathrm{C}$. After centrifugation, the supernatant was collected to obtain the aqueous extract and the precipitate was discarded.

The proline was obtained using the method described by Bates et al. (1973) in which $50 \mathrm{mg}$ of lyophilized dry mass (DM) were transferred to $15 \mathrm{~mL}$ test tubes, adding $5 \mathrm{~mL}$ of distilled water and placed in a water bath for $30 \mathrm{~min}$ at $100{ }^{\circ} \mathrm{C}$. After extraction, the samples were centrifuged in a bench centrifuge $(1000 \mathrm{rpm})$ and the supernatants were collected to obtain the total extract.

\section{Data analysis}

Analysis of variance (ANOVA) was performed for a completely randomized design. Means were compared using the Tukey test, at a significance level of $\alpha=5 \%$. Statistics were analyzed using the SAS system (SAS version 9.1, SAS institute, Cary, NC, USA, 1987).

\section{Results}

\section{Concentrations of starch and sucrose}

In both species the control had the highest average starch content $\left(0.18\right.$ and $0.3 \mathrm{mmol} \mathrm{g}^{-1}$ of residue). Minimum

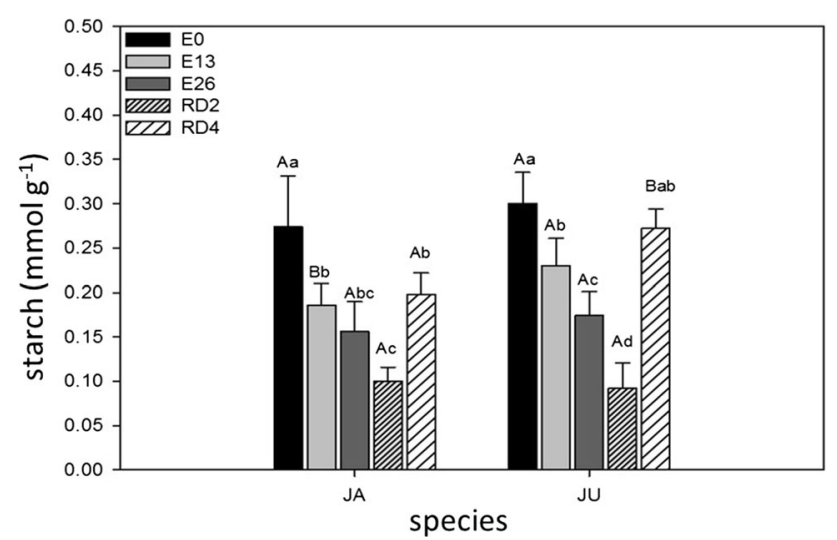

Fig. 1 Starch concentrations in H. Courbaril (JA) and H. stigonocarpa (JU) due to the weather. Non-stressed plants (E0), plants stressed for 13 days (E13), 26 days (E26) and plants rehydrated for 2 days (RD2) and 4 days (RD4). The values shown are the means and standard deviation of all measurements. In the chart, bars identified with uppercase letters represent the difference between the two species in treatments E0 (CV: 16.58), E13 (CV: 13.30), E26 (CV: 18.48), RD2 (CV: 24.09) and RD4 (CV: 9.70). When the bars were labeled with different lowercase letters, they represented the difference between the periods (times) in the species JA (CV: 18.58) and JU (CV: 13.60). Means were compared using the Tukey's test $(p<0.05)$ starch content was recorded for time RD2 $\left(0.19 \mathrm{mmol} \mathrm{g}^{-1}\right.$ of residue for species JA and $0.09 \mathrm{mmol} \mathrm{g}^{-1}$ of residue for species JU (Fig. 1).

Controls (E0) for both species (JA $=24.93 \mathrm{mg} \mathrm{g}^{-1}$ and $\mathrm{JU}=18.66 \mathrm{mg} \mathrm{g}^{-1}$ of MS) presented the lowest sucrose values (Fig. 2). The treatments E26 (JA $=35.21 \mathrm{mg} \mathrm{g}^{-1}$ and $\mathrm{JU}=27.02 \mathrm{mg} \mathrm{g}^{-1}$ of $\mathrm{MS}$ ) and RD2 $\left(\mathrm{JA}=38.40 \mathrm{mg} \mathrm{g}^{-1}\right.$ and $\mathrm{JU}=33.08 \mathrm{mg} \mathrm{g}^{-1}$ of $\left.\mathrm{MS}\right)$ showed the highest sucrose concentrations.

\section{Concentrations of proline and glycine-betaine (GB)}

Treatment RD2 $\left(\mathrm{JA}=7.19 \mu \mathrm{mol} \mathrm{g}^{-1}\right.$ of $\mathrm{MS}$ and $\mathrm{JU}=5.19 \mu \mathrm{mol} \mathrm{g}^{-1}$ of MS) for both species had the highest proline levels (Fig. 3).

GB content was significantly greater with increasing stress levels (Fig. 4). Larger additions of GB were recorded for treatments E26 and RD2 with the respective means of 16.85 and $18.52 \mu \mathrm{g}$ of $\mathrm{GB}^{-1}$ MS for species JA. For species JU, mean GB was lower at 8.80 and $11.06 \mu \mathrm{g}$ of glycine-betaine $\mathrm{g}^{-1} \mathrm{MS}$, respectively. The control showed lowest concentrations of GB for both species.

When irrigation was resumed, some concentrations reacquired pre-stress levels. Although water deficiency altered the concentrations of all solutes, after rehydration they returned to normal, indicating that the water deficit period (26 days) did not cause irreversible stress.

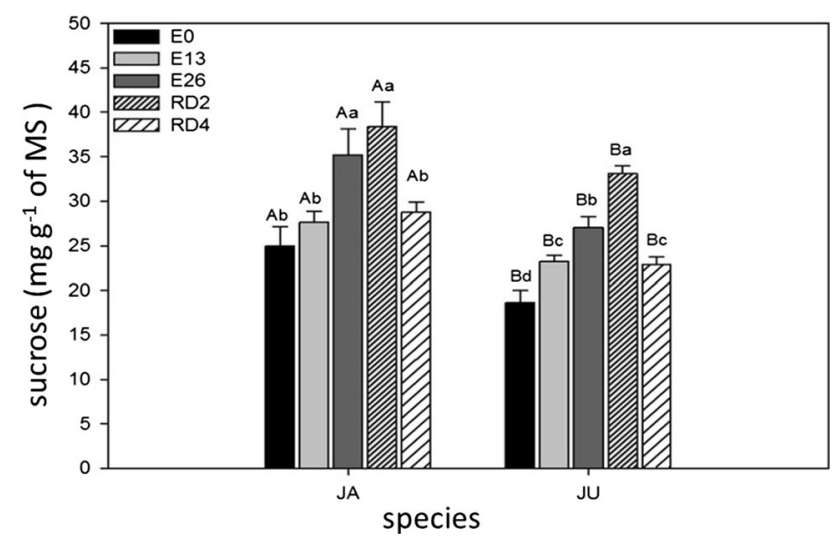

Fig. 2 Concentration of sucrose in JA $(H$. courbaril) and JU $(H$. stigonocarpa) due to the weather. Non-stressed plants (E0), plants stressed for 13 days (E13), 26 days (E26) and plants rehydrated for 2 days (RD2) and 4 days (RD4). The values shown are the means and standard deviation of all measurements. In the chart, bars identified with uppercase letters represent the difference between the two species in treatments E0 (CV: 8.25), E13 (CV: 3.90), E26 (CV: 7.22), RD2 (CV: 5.78) and RD4 (CV: 3.92). When the bars were labeled with different lowercase letters, they represented the difference between the periods (times) in the species JA (CV: 7.03) and JU (CV: 4.14). Means were compared using the Tukey's test $(p<0.05)$ 


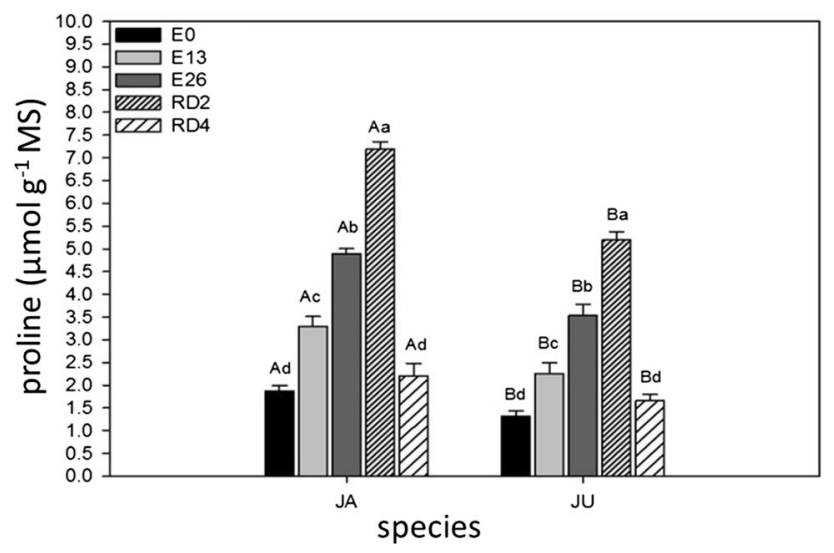

Fig. 3 Concentration of proline in JA $(H$. courbaril) and JU $(H$. Stigonocarpa) due to the weather. Non-stressed plants (E0), plants stressed for 13 days (E13), 26 days (E26) and plants rehydrated for 2 days (RD2) and 4 days (RD4). The values shown are the means and standard deviation of all measurements. In the chart, bars identified with uppercase letters represent the difference between the two species in treatments E0 (CV: 7.33), E13 (CV: 8.19), E26 (CV: 4.60), RD2 (CV: 2.87) and RD4 (CV: 11.77). When the bars were labeled with different lowercase letters, they represented the difference between the periods (times) in the species JA (CV: 4.97) and JU (CV: 2.79). Means were compared using the Tukey's test $(p<0.05)$

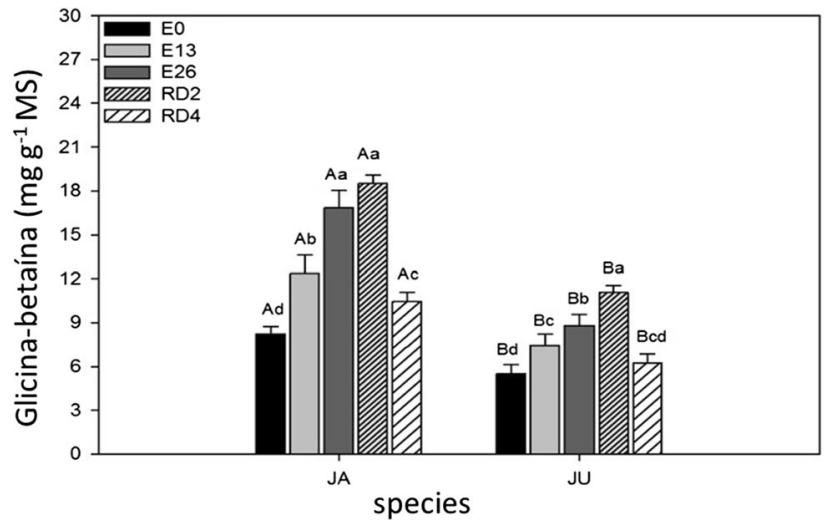

Fig. 4 Glycine-betaine (GB) in JA (H. courbaril) and JU (H. stigonocarpa) due to the weather. Non-stressed plants (E0), plants stressed for 13 days (E13), 26 days (E26) and plants rehydrated for 2 days (RD2) and 4 days (RD4). The values shown are the means and standard deviation of all measurements. In the chart, bars identified with uppercase letters represent the difference between the two species in treatments E0 (CV: 8.36), E13 (CV: 10.48), E26 (CV: 12.82), RD2 (CV: 3.45) and RD4 (CV: 7.29). When the bars were labeled with different lowercase letters, they represented the difference between the periods (times) in the species JA (CV: 4.97) and JU (CV: 2.79). Means were compared using the Tukey's test $(p<0.05)$

\section{Discussion}

\section{Concentrations of starch and sucrose}

The decline in starch concentration was due to increased activity of enzymes responsible for starch hydrolysis, such as $\alpha$ - and $\beta$-amylase enzymes, and also to the accumulation of sugars in plants subjected to water deficiency. Thus, when the reserve polysaccharides were mobilized, the product of the hydrolysis was usually sucrose, which is considered the main transporting sugar in plants.

The reduction in starch concentration was not accompanied by an increase in soluble sugars content, which is indicative of consumption of these sugars to keep plants alive, even in drought conditions in plants subjected to eleven days of water stress (Melo et al. 2007).

The increase in sucrose concentration probably occurred due to the degradation of the starch by the sugars of the $\alpha$ and $\beta$-amylase enzymes. In addition, this sugar can be broken and the starch processed through biochemical reactions, turning it into sucrose. Among the various sugars formed, sucrose is the principal one and is transported by the plant. The results obtained in this work were similar to those reported by Brito et al. (2016), in which young $H$. courbaril L. plants submitted to water stress and flood confirmed that leaves of plants submitted to water deficiency (36.875 $\mathrm{mg} \mathrm{g}^{-1}$ MS sucrose) showed higher sucrose concentrations when compared to leaves of control plants $\left(27,622 \mathrm{mg}\right.$ sucrose $\left.\mathrm{g}^{-1} \mathrm{MS}\right)$ and flooded plants (15,533 $\mathrm{mg}$ sucrose $\left.\mathrm{g}^{-1} \mathrm{MS}\right)$. Liu et al. (2011) reported that sucrose content gradually increases in plants subjected to water deficiency and this may be related to degradation of biological membranes due to water stress in the cytosol of the plant and also the elevations in the content of ionic substances, which entails the inactivation of several enzymes in the cytosol.

\section{Concentrations of proline and glycine-betaine (GB)}

Proline is an osmoregulator important in the protection of plants submitted to abiotic stresses, favoring both osmotic adjustment and increase in the contents of other osmolytes. This result has been demonstred by Taiz and Zeiger (2006) and Ashraf and Foolad (2007).

The formation of amino acids through protein degradation and high levels of ammonia might explain the higher increases in glycine betaine contents in plants submitted to water deficit (Mcneil et al. 1999).

Sakamoto and Murata (2002) reported that changes in concentrations of GB are probably due to its function as an osmoregulator, but also to its function in stabilizing the structures and activities of enzymes of the protein complex, and maintaining the integrity of membranes from the damaging effects of different abiotic stresses. Nascimento (2009) reported that $H$. courbaril performs osmotic adjustment when exposed to water stress. Nascimento et al. (2015) verified that jatobá plants in water deficit condition present a osmotic adjustment due to the increase of the turgor in the leaf. 


\section{Conclusions}

Young $H$. courbaril and $H$. stigonocarpa plants are influenced by water deficiency and rehydration, in which the osmotic adjustment in the leaves occurred to maintain the cellular turgescence. These species can adapt to adverse conditions of abiotic stress.

Acknowledgements The authors are grateful to the Universidade Federal Rural da Amazônia for the financial support of this work and the collaborations of researchers.

\section{References}

Barbosa LM, Martins SE (2003) Diversificando o reflorestamento no estado de São Paulo: espécies disponíveis por região e ecossistema. Instituto de Botânica, São Paulo, p 63

Bates LS, Waldren RP, Teare ID (1973) Rapid determination of free proline for water-stress studies. Plant Soil 39(1):205-207

Batista CUN, Medri ME, Bianchini E, Medri C, Pimenta JA (2008) Tolerância à inundação de CecropiapachystachyaTrec. (Cecropiaceae): aspectos ecofisiológicos e morfoanatômicos. Acta Bot Bras 22(1):91-98

Brito AEA, Palheta JG, Costa AS, Sousa JCM, Nascimento VR, Machado LC, Martins JTS, Costa TC, Nogueira GA, Andrade Júnior WV, Filho BGS, Costa TC (2016) Growth and ecophysiological aspects in young plants of (Hymenaea courbaril L.) submitted to water stress and flooding. Int $\mathrm{J}$ Curr Res 8(7):34647-34654

Carlin SD, Santos DMM (2009) Indicadores fisiológicos da interação entre déficit hídrico e acidez do solo em cana-de-açúcar. Pesquisa Agropecuária Brasileira 44(9):1106-1113

Dubois M, Gilles KA, Hamilton JK, Rebers PA, Smith F (1956) Colorimetric method for determination of sugars and related substances. Anal Chem 28(3):350-356

Grennan AK (2006) Abiotic stress in rice. An "Omic" approach. Plant Physiol 140(4):1139-1141

Grieve CM, Grattan SR (1983) Rapid assay for determination of water soluble quaternary ammonium compounds. Plant Soil 70(2):303-307

Kavi kishor PB, Sangam S, Amrutha RN, Sri laxmi P, Naidu KR, Rao KRSS, Rao S, Reddy KJ, Theriappan P, Sreeniv N (2005) Regulation of proline biosynthesis, degradation, uptake and transport in higher plants: its implications in plant growth and abiotic stress tolerance. Curr Sci 88(3):424-438

Larcher W (2006) Ecofisiologia Vegetal. Tradução: Prado CHBA. São Carlos: Rima
Liu C, Liu C, Liu Y, Guo K, Fan D, Li G, Zheng Y, Yu L, Yang R (2011) Effect of trought on pigments, osmotic adjustment and antioxidante enzymes in six Woody plant species in karst habitats of southwestern China. Environ Exp Bot 71(2):174-183

Lopes JLW, Guerrini IA, Silva MR, Saad JCC, Lopes CF (2011) Estresse hídrico em plantio de eucalyptus grandis vs. eucalyptus urophylla, em função do solo, substrato e manejo hídrico de viveiro. Revista Árvore 35(1):31-39

Mcneil SD, Nuccio ML, Hanson AD (1999) Betaines and related osmoprotectants. Targets for metabolic engineering of stress resistance. Plant Physiol 120:945-949

Melo HC, de Castro E, Soares ÂM, de Melo LA, Alves JD (2007) Alterações anatômicas e fisiológicas em Setaria anceps Stapfex Massey e Paspalum paniculatum L. sob condições de déficit hídrico. Hoehnea 34(2):145-153

Nascimento HHC (2009) Caracterização ecofisiologica de mudas de Jatobá (Hymenaea courbaril L.) submetidas a déficit hídrico. Dissertação (Mestrado)-Universidade Federal Rural de Pernambuco

Nascimento HHC, Nogueira RJMC, Silva EC, Silva MA (2011) Análise do crescimento de mudas de jatobá (Hymenaea courbaril L.) em diferentes níveis de água no solo. Revista Árvore 35(3):617-626

Nascimento HHC, Santos CA, Freire CS, Silva MA, Nogueira RJMC (2015) Ajustamento osmótico em mudas de jatobá submetidas à salinidade em meio hidropônico. Revista Árvore 39(4):641-653

Paiva HN, Vital BR (2003) Escolha da espécie florestal. Universidade Federal de Viçosa, Viçosa. (Cadernos Didáticos, 93)

Pimentel C (1999) Relações hídricas em dois híbridos de milho sob dois ciclos de deficiência hídrica. Pesquisa Agropecuária Brasileira 34(11):2021-2027

Pimentel C (2004) A Relação da Planta com a Água. Seropédica, Rio de Janeiro, p 191

Sakamoto A, Murata N (2002) The role of glycine-betaine in the protection of plants from stress: clues from transgenic plants. Plant Cell Environ 25(2):163-171

Santos Filho BG, Neto CFO, Alves GAR, Lobato AKS, Costa RCL. 2010. Potencial hídrico e ajustamento osmótico em plantas jovens de jatobá (Hymenaea courbaril L.) oriundas de sementes da base petrolífera geólogo 'Pedro de Moura' em Urucu, município de Coari, AM submetidas à deficiência hídrica e alagamento. III Reunião Científica da Rede CTPetro Amazônia-Manaus. http://projetos.inpa.gov.br/ctpetro/IIIReuniao/Arti gosReuniao/PT1/Resumos/PT1\%2002.pdf. Accessed 10 Jan 2017

SAS Institute (1987) SAS—statistical analysis system: system for elementary statistical analysis. SAS Institute, Cary, p 416

Van Handel E (1968) Direct microdetermination of sucrose. Anal Biochem 22(2):280-283 